\title{
Comparison of SYBR green I real-time RT-PCR with conventional agarose gel-based RT-PCR for the diagnosis of infectious bronchitis virus infection in chickens in Morocco
}

\author{
Siham Fellahi ${ }^{1,2}$, Mehdi El Harrak ${ }^{3}$, Jens H. Kuhn4, Ghizlane Sebbar ${ }^{3}$, El Arbi Bouaiti ${ }^{5}$, Khadija Khataby², \\ Ouafae Fassi Fihri ${ }^{1}$, Mohammed El Houadfi ${ }^{1 \dagger}$ and My Mustapha Ennaji ${ }^{2^{*}}$
}

\begin{abstract}
Background: A rapid, sensitive, and specific molecular method for the diagnosis of infectious bronchitis virus (IBV) infection is important in curbing infectious bronchitis outbreaks in Morocco and other countries.

Methods: In this study, an easy-to-perform SYBR green I real-time reverse transcriptase polymerase chain reaction (RT-PCR) targeting the nucleocapsid gene of IBV was developed and compared with conventional agarose gel-based RT-PCR for the detection of IBV infection.

Results: We found that the SYBR green I real-time RT-PCR was at least 10 times more sensitive than the agarose gel electrophoresis detection method. The assay exhibited high specificity for IBV infection. All negative controls, such as Newcastle disease virus, infectious bursal disease virus, and avian influenza virus, were not detected.

Conclusion: The SYBR green I real-time RT-PCR test described herein can be used to rapidly distinguish IBV from other respiratory pathogens, which is important for diagnosis and control of infectious bronchitis outbreaks in Morocco. The test is a valuable and useful method as a routine assay for diagnosis of clinical IBV infection in commercial chickens.
\end{abstract}

Keywords: Coronavirus, Gammacoronavirus, IBV, Infectious bronchitis virus, SYBR green, Real time RT-PCR, RT-PCR

\section{Background}

Infectious bronchitis (IB), an acute, highly contagious viral upper respiratory disease of chickens, is one of the most economically significant diseases hampering the intensive poultry industry worldwide. IB affects chickens of all ages, causing respiratory, reproductive, and renal manifestations [1]. Although control of IBV infection is primarily achieved through live attenuated vaccines, the

\footnotetext{
*Correspondence: m.ennaji@yahoo.fr

${ }^{\dagger}$ Mohammed El Houadfi and My Mustapha Ennaji contributed equally to this work

${ }^{2}$ Laboratory of Virology, Microbiology and Quality/Ecotoxicology \& Biodiversity, Faculty of Sciences and Techniques-University Hassan II Mohammedia, PO Box 146, Quartier Yasmina-Mohammedia, 20650 Casablanca, Morocco

Full list of author information is available at the end of the article
}

infection is difficult to contain because immunization with different serotypes of the virus do not necessarily cross-protect against other serotypes [2]. Within an infected poultry flock, quick and accurate detection of the presence of the virus is imperative to properly vaccinate uninfected flocks. In addition, rapid differentiation of IBV infection from other upper respiratory tract diseases (e.g., avian influenza, Newcastle disease, infectious laryngotracheitis, avian mycoplasmosis) is important so that appropriate measures can be taken in a timely manner [3].

IB is a disease that negatively impacts the poultry industry of developing countries. For instance, in Morocco, IB continues to be an uncontrolled problem [4-6] due to the lack of in-country diagnostic capabilities that can be performed quickly and interpreted easily 
by local staff in potentially underequipped or otherwise challenging environments.

The causative agent of IB, infectious bronchitis virus (IBV), is a member of the species Avian coronavirus, genus Gammacoronavirus, family Coronaviridae [7]. IBV is an enveloped, positive-sense, single-stranded RNA virus (genome length $=27.6 \mathrm{~kb}$ ) [8], expressing three major structural proteins: the nucleocapsid protein $(\mathrm{N})$ surrounding the viral RNA, the membrane glycoprotein $(\mathrm{M})$, and the spike glycoprotein (S) located on the surface of the viral envelope. The $S$ protein contains two posttranslational subunits, S1 and S2 [9].

Current diagnostic assays for IBV include virus isolation in embryonated eggs, tracheal organ culture, cell culture immunoassays, and molecular assays that detect viral RNA [10]. Virus isolation has been considered to be the reference standard. However, such isolations are expensive and time consuming because several passages may be required to detect the virus. Immunoassays use IBV-specific monoclonal antibodies to detect the virus in direct or indirect fluorescent antibody and enzyme-linked immunosorbent assay (ELISA) formats. Although faster and simpler than virus isolation, immunoassays tend to lack specificity and sensitivity. None of these immunoassays detect all strains or types of IBV [11-13]. Molecular assays, such as reverse transcriptase-polymerase chain reaction (RT-PCR), for the detection of IBV are commonly used because highly specific and sensitive results can be obtained in a timely manner. Molecular assays detect viral RNA directly from a clinical sample or from virus isolated in a laboratory host system. When RT-PCR is used to amplify the spike glycoprotein (S) of IBV, the assay can be coupled with restriction fragment length polymorphism analysis or nucleic acid sequencing to identify serotypes of the virus $[2,10,12-16]$. More recently, many fluorescent probe-based real-time RTPCR assays have been developed to detect IBV strains $[2,3,9,10,15,17]$. Real-time TaqMan RT-PCR assays have been developed that amplify a fragment of the $5^{\prime}$ untranslated region of the IBV genome to detect turkey coronaviruses and IBV [17] or that target the $\mathrm{N}$ gene for IBV detection [9].

Unfortunately, performing most of these assays requires highly trained staff, a sophisticated infrastructure, or considerable monetary funds, and are therefore not necessarily viable options for developing countries such as Morocco. SYBR green I-based RT-PCR assays have proven to be among the most effective tools in the rapid and differential detection of a variety of viral diseases such as avian influenza, Newcastle disease, and IB. These inexpensive and easily performed assays are important to rapidly identify the causative agent of any upper respiratory disease or changes in egg shell quality and egg production in chickens $[17,18]$.

However, an assay employing real-time RT-PCR with SYBR green I dye to target the $\mathrm{N}$ gene of IBV is lacking. Here we report the development of a real-time RT-PCR assay with SYBR green I dye for rapid detection of IBV viral RNA directly from Moroccan clinical samples. We also compared the assay with conventional RT-PCR and agarose gel electrophoresis to detect IBV PCR-amplified products.

\section{Results \\ Reproducibility \\ SYBR green I real-time RT-PCR}

The cDNA IBV Beaudette strain (infectious bronchitis virus/G.gallus-wt/FRA/1995/Beaudette) was used to extract the standard control genomic RNA that then served as the source of cDNA template. Concentrations of the cDNA standard ranging from $10-10^{6}$ copies/ $\mu \mathrm{l}$ were tested repeatedly (Fig. 1) by SYBR green-I-based real-time RT PCR. The results are reproducible through $10 \mathrm{cDNA}$ copies $/ \mu \mathrm{l}$.

\section{Conventional gel-based RT-PCR}

The PCR targeted a sequence corresponding to a region of the IBV N protein. The obtained PCR products of $130 \mathrm{bp}$ in length were separated on a $1.5 \%$ agarose gel stained with ethidium bromide (Fig. 2). PCR products were detectable at a dilution of $100 \mathrm{cDNA}$ copies/ $\mu \mathrm{l}$.

\section{Specificity of SYBR green I real-time RT-PCR}

Melting peaks analysis on the PCR products of H120, MA5, and 4/91 vaccine strains and tenfold serially diluted cDNA (data not shown) did not indicate primerdimers or nonspecific products. Specific amplification of

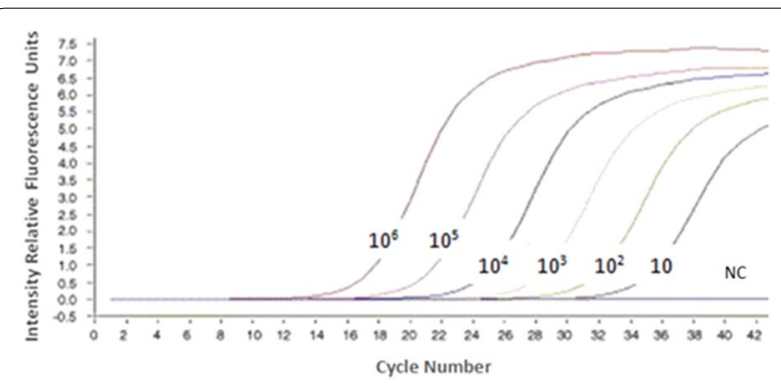

Fig. 1 Real-time reverse transcriptase polymerase chain reaction for detection of infectious bronchitis virus. CDNA derived from IBV Beaudette strain genomic RNA was diluted serially from $10^{6}$ to $10^{1}$ copies/ $\mu \mathrm{l}$ and detected by real-time PCR. The $x$-axis indicates the PCR cycle number, whereas the $y$-axis indicates the fluorescence intensity over the background. NC negative control, PCR polymerase chain reaction 


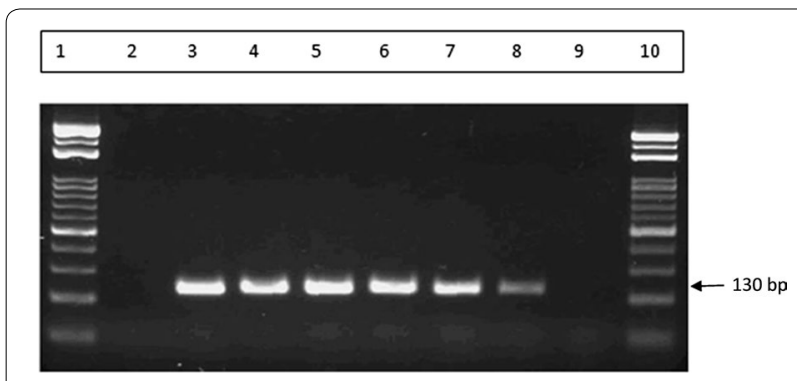

Fig. 2 Agarose gel electrophoresis of conventional RT-PCR amplified products from infectious bronchitis virus $\mathrm{N}$ gene. Electrophoresis of PCR amplification after serial dilutions of the IBV Beaudette strain in a $1.5 \%$ agarose gel stained with ethidium bromide. Lanes 1 and 10 50-bp DNA ladder; lane 2 negative control; lane $310^{8} \mathrm{copies} / \mu \mathrm{l}$; lane $410^{7} \mathrm{copies} / \mu \mathrm{l}$; lane $510^{6} \mathrm{copies} / \mu \mathrm{l}$; lane $610^{5} \mathrm{copies} / \mu \mathrm{l}$; lane 7 $10^{4}$ copies $/ \mu$ l; lane $810^{3}$ copies $/ \mu$ l; lane $910^{2}$ copies $/ \mu$ l. bp base pairs, $I B V$ infectious bronchitis virus, RT-PCR reverse transcriptase-polymerase chain reaction

the IBV target sequence was identified by the generation of a melt peak at $68 \pm 0.20^{\circ} \mathrm{C}$. The specificity of the SYBR green-I real-time RT-PCR was $100 \%$ since detectable fluorescent signals were not observed with the negative control (NC), avian influenza virus (FLUAV), infectious bursal disease virus (IBDV), and Newcastle Disease virus (NDV) nucleic acids. Only the IBV vaccine strain genetic material was detected (Fig. 3).

\section{Sensitivity}

\section{SYBR green I real-time RT-PCR}

To determine the sensitivity endpoint of the assay, serial dilutions of cDNA at concentrations ranging from 1.25 to $100 \mathrm{copies} / \mu \mathrm{l}$ were analyzed. The real-time RT-PCR fluorescence curve derived from serially diluted standard concentrations (cDNA of $\mathrm{H} 120$ vaccine strain) indicates a high sensitivity of detection down to 100 copies/ $\mu$ l of cDNA (Fig. 4).

To determine the linearity of the reaction and the RTPCR efficiency, the cycle threshold $(\mathrm{Ct})$ values of individual dilutions were analyzed. The assay has a dynamic detection range that spanned $10^{2}-10^{6} \mathrm{cDNA}$ copies $/ \mu$ l. Except for the undiluted cDNA, a strong inverse linear relationship was observed between the amount of input cDNA and the Ct values over six $\log _{10}$ dilutions (Table 1 ), as indicated by a simple linear regression plot of the two variables (Fig. 5).

\section{Conventional RT-PCR}

Results from a conventional RT-PCR using the IBV N gene confirmed that the obtained RT-PCR products were $130 \mathrm{bp}$ in length, and the PCR products were detectable at a concentration of 100 copies/ $\mu$ l (Fig. 6).
Comparison of sensitivity and specificity of the SYBR green I real-time RT-PCR assay with conventional RT-PCR

The lowest dilution of cDNA that SYBR green I real-time RT-PCR assay was able to detect was an order of magnitude higher than conventional RT-PCR assay (Table 1). Receiver operating characteristic curve analysis of $\mathrm{Ct}$ values obtained from the SYBR green I real-time RT-PCR assay indicates the linearity of the reaction and the assay's efficiency (Fig. 7). The assay has a maximum sensitivity and specificity over a detection range that spanned $10^{4}$ cDNA gene copies/ $\mu \mathrm{l}$ (Table 1$)$.

\section{Detection of IBV in tracheal swabs from clinical samples}

The optimized methods of SYBR green I real-time RTPCR and conventional RT-PCR were applied to clinical samples from broiler chickens showing clinical signs of $\mathrm{IB}$, including coughing, sneezing, rales, and nasal discharge. From 34 tracheal swabs tested, all samples and positive controls were positive for IBV by SYBR green I real-time RT-PCR targeting the IBV N gene (data not shown and Fig. 8 for a subset of the total swabs tested). However, only 28 of 34 samples were positive for IBV by conventional RT-PCR (data not shown).

\section{Intra- and inter-assay variability}

The SYBR green I real-time RT-PCR assay demonstrated high repeatability with coefficients of variation within runs (intra-assay variability) and between runs (interassay variability) that ranged from $0.6-1.5$ and $0.6-1.8 \%$, respectively (Table 2 ).

\section{One-step RT PCR amplification of the IBV S1 gene and sequence analysis}

For further confirmation of our results, we investigated whether tracheal samples that tested IBV-positive using SYBR green I real-time RT-PCR targeting the IBV N gene would also be positive using a one-step RT-PCR targeting the IBV S1 gene. The IBV S1 gene of IBV commercial vaccine strains (H120, Ma5 and 4/91) and field strains "Moroccan 30" and "Moroccan 38" (randomly chosen from the 34 broiler chicken samples) were detected and amplified using a one-step RT-PCR. The obtained RTPCR product, $700 \mathrm{bp}$, corresponded to the predicted size (Fig. 9) [19]. The obtained sequences were aligned with those of IBV deposited in GenBank (H120 [M21970]; Ma5 [AY561713]; Italy 02 [AJ457137]; Italy 497/02-1 [DQ901377]; Ark/C6d [EU283056]; QX [AF193423]; strain 04/1991 [AF093794]; and D274 [X15832]), using the BLAST software. The results of sequenced field strains compared to IBV reference strains confirm that the amplified sequences corresponded to the IBV reference strains [GenBank: KJ701019 and KJ701020]. 


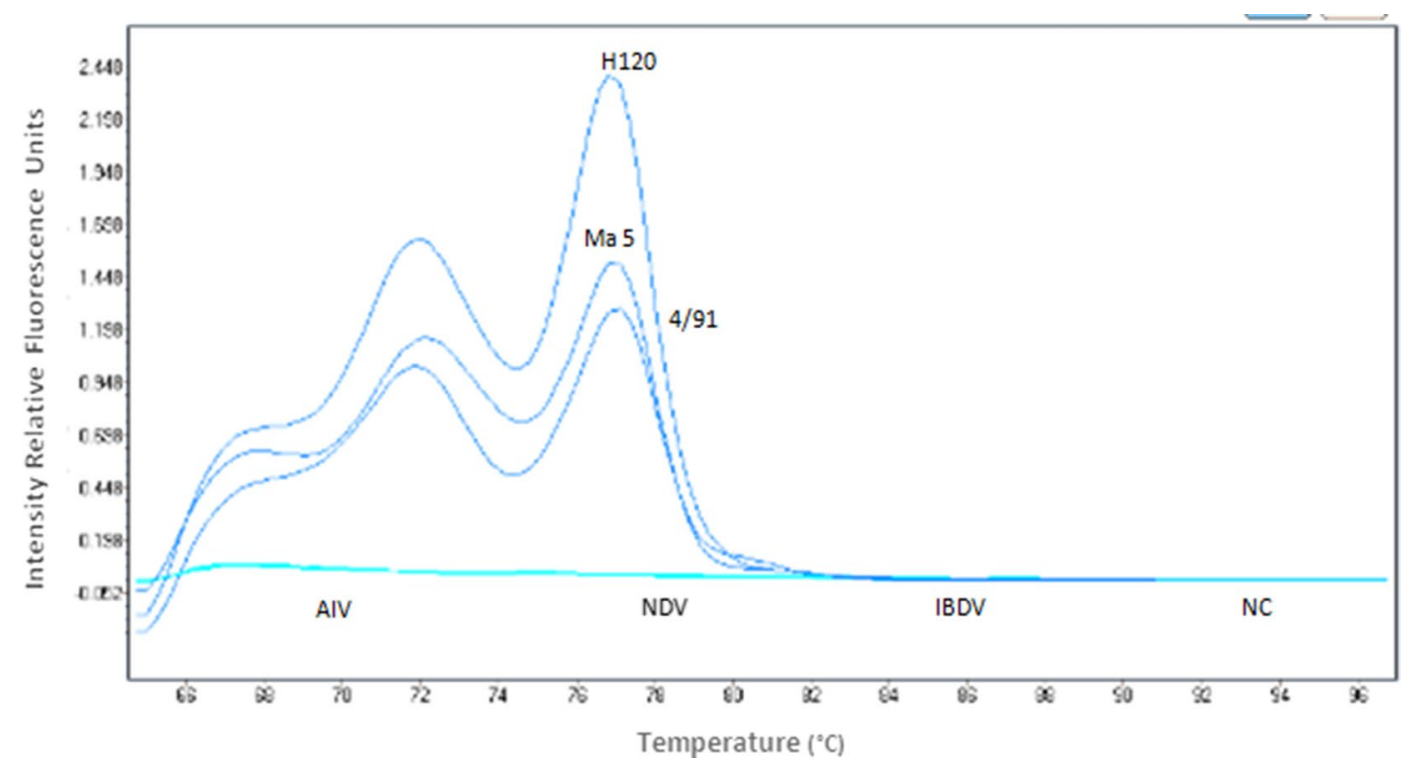

Fig. 3 Specificity of IBV N gene-based SYBR green I real-time RT-PCR. Amplification plot representing IBV (H120, Ma5, 4/91), FLUAV, IBDV, NDV, and negative control (NC). The blue curve shows the amplification plots of the IBV-positive samples while the turquoise curve shows the plots of the IBVnegative strains. FLUAV avian influenza virus A, IBV infectious bronchitis virus, IBDV infectious bursal disease virus, NDV newcastle disease virus

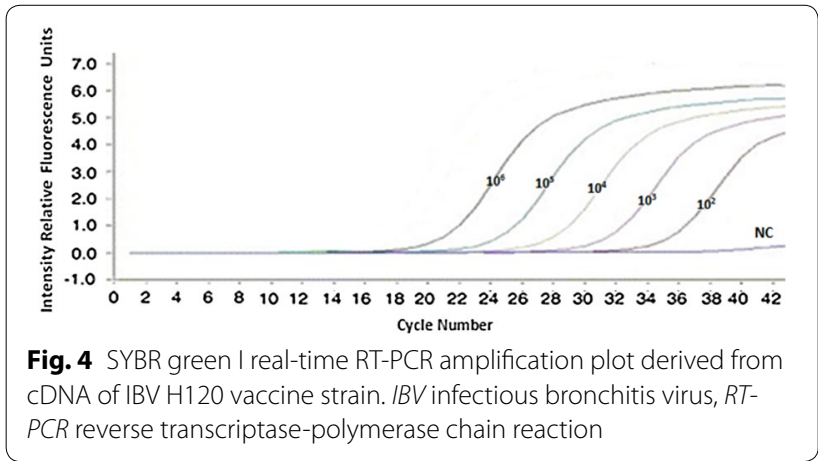

CDNA of IBV H120 vaccine strain. IBV infectious bronchitis virus, RT-

$P C R$ reverse transcriptase-polymerase chain reaction

\section{Discussion}

The use of PCR for diagnosis of viral diseases has increased to the point that the assay is now considered the gold standard instead of viral isolation [20]. Real-time PCR has catalyzed wider acceptance of PCR as a diagnostic tool because it is more rapid, sensitive, and reproducible, and the risk of carryover contamination is minimized compared to conventional PCR [21].

Diagnosis of IB is commonly based on virus isolation in embryonated eggs, followed by immunological identification of the isolates. This procedure is time consuming and requires use of specific polyclonal or monoclonal

Table 1 Sensitivity and specificity of Sybr green I real-time RT-PCR in detection of CDNA from the IBV H120 vaccine strain compared to conventional RT-PCR agarose gel electrophoresis

\begin{tabular}{|c|c|c|c|c|c|c|c|}
\hline \multirow{4}{*}{$\begin{array}{l}\text { CDNA concentration } \\
\left(\log _{10} \text { copies } / \mu \mathrm{l}\right)\end{array}$} & \multicolumn{7}{|c|}{ Detection method } \\
\hline & \multicolumn{6}{|c|}{ SYBR green I real-time RT-PCR } & \multirow{3}{*}{$\begin{array}{l}\text { Conventional } \\
\text { RT-PCR } \\
\text { P/N }\end{array}$} \\
\hline & \multirow[t]{2}{*}{ Ct value } & \multicolumn{2}{|c|}{ Sensitivity } & \multicolumn{2}{|c|}{ Specificity } & \multirow[t]{2}{*}{$\mathrm{P} / \mathrm{N}$} & \\
\hline & & $\%$ & $\mathrm{Cl}$ & $\%$ & $\mathrm{Cl}$ & & \\
\hline $10^{1}$ & 36.31 & 0 & $0-69.5$ & 100 & $19.3-100$ & - & - \\
\hline $10^{2}$ & 33.19 & 33.33 & $5.5-88.4$ & 100 & $19.3-100$ & + & - \\
\hline $10^{3}$ & 26.59 & 66.67 & $11.6-94.5$ & 100 & $19.3-100$ & + & + \\
\hline $10^{4}$ & 24.79 & 100 & $30.5-100$ & 100 & $19.3-100$ & + & + \\
\hline $10^{5}$ & 21.90 & 100 & $30.5-100$ & 50 & $8.2-91.8$ & + & + \\
\hline $10^{6}$ & 17.29 & 100 & $30.5-100$ & 0 & $0-80.7$ & + & + \\
\hline
\end{tabular}

Cl confidence interval, $C t$ average cycle threshold, RT-PCR reverse transcriptase-polymerase chain reaction, + positive $(\mathrm{P}),-$ negative $(\mathrm{N})$ 


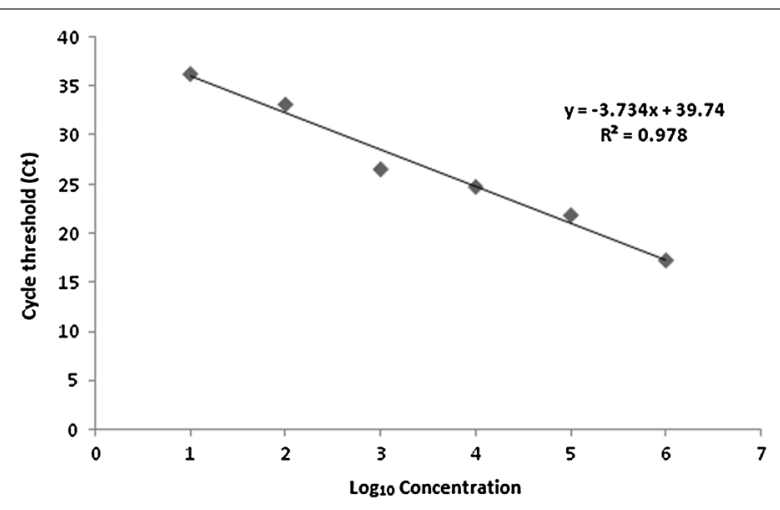

Fig. 5 Simple linear regression line of $C t$ values vs. $\log _{10}$ of tenfold serial dilutions $\left(10^{6}-10\right.$ copies/ $\mu$ l) of standard RNA genome of CDNA of $\mathrm{H} 120$ vaccine strain. Ct cycle threshold

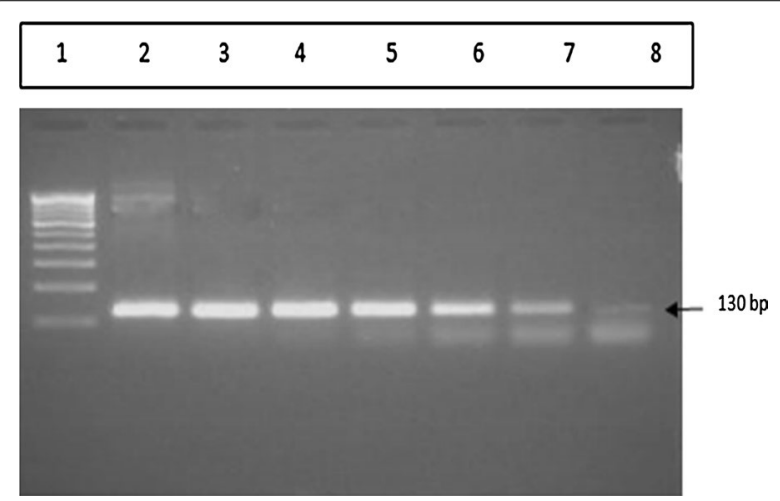

Fig. 6 Agarose gel electrophoresis of conventional RT-PCR products from the N gene of IBV H120 strain. Amplified products were separated by electrophoresis on a $1.5 \%$ agarose gel and stained with ethidium bromide. Lane 1100 bp DNA ladder; lane $210^{7}$ copies/ $\mu$; lane $310^{6}$ copies $/ \mu$ l; lane $410^{5}$ copies $/ \mu l$; lane $510^{4}$ copies $/ \mu$ l; lane 6

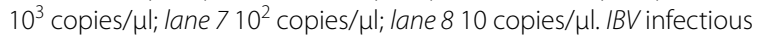
bronchitis virus, $R T-P C R$ reverse transcriptase-polymerase chain reaction

antibodies, which may not be available. Moreover, some isolates could be mixtures of different serotypes of IBV that can confuse interpretation of results. RT-PCR techniques using RNA extracted from allantoic fluid and tracheal swabs from IBV-infected chickens are very efficient in the detection of IBV $[22,23]$. However, conventional RT-PCR is time consuming, prone to error, and is less sensitive than real-time RT-PCR [3, 9, 24-26].

With the SYBR green I real-time RT-PCR assay that we developed, we compared the performance of this novel technique to conventional agarose gel-based RT-PCR in detecting specific IBV RT-PCR products. Based on serially diluted cDNA standards, the SYBR green I real-time RT PCR detected down to 100 cDNA copies/ $\mu$ lof the IBV H120 vaccine strain genomic material. The SYBR green I real-time RT PCR assay targeting the highly conserved N

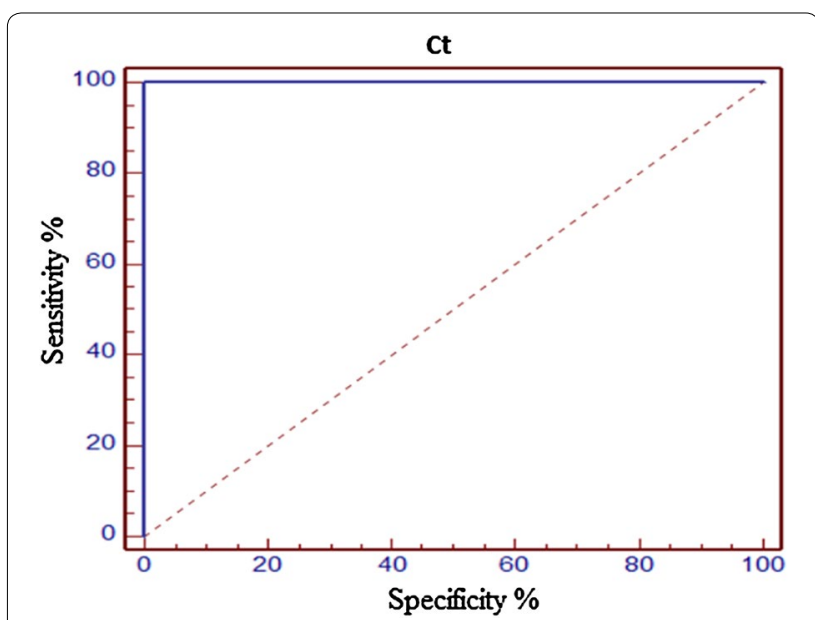

Fig. 7 Receiver operating characteristic curve analysis of Ct values obtained from SYBR green-I-based real-time RT-PCR versus conventional RT-PCR. RT-PCR reverse transcriptase-polymerase chain reaction

gene has a higher sensitivity than conventional RT-PCR in detecting IBV nucleic acids. Targeting the $\mathrm{N}$ gene has been postulated to be a better choice to improve the sensitivity of the PCR compared to the S1 gene, as the N protein is abundant in infected cells $[9,27]$.

The specificity of our test was demonstrated by the absence of positive reactions with genetic material obtained from other RNA viruses, such as FLUAV, IBDV, and NDV (Fig. 3). The optimal melting peak of IBV amplicons strains is $68 \pm 0.20^{\circ} \mathrm{C}$. No primer-dimer or nonspecific products were detected. These results are comparable with previously reported SYBR green I realtime RT-PCR assays established for coronaviruses and type-specific IBV multiplex SYBR green I real-time RTPCR [24, 28].

SYBR green I real-time RT-PCR and conventional RTPCR were applied to 34 clinical samples obtained from Moroccan broiler chicken flocks showing clinical signs of IB. IBV N gene amplification with SYBR green I real-time RT-PCR detected all the IBV strains assessed, whereas only 28 of 34 clinical swabs tested were positive for IBV by conventional RT-PCR. The increased sensitivity of real-time RT-PCR compared to conventional RT-PCR might be due to detection of the fluorescent signal emitted by specific amplification products [24]. Therefore, the SYBR green I real-time RT-PCR assay developed here using Moroccan field cases could be an important tool for the screening of samples during IB-suspected cases as the assay is rapid, simple, efficient, highly specific, and sensitive.

Recently, real-time RT-PCR assays were described that can detect IBV either solely or in a multiplex set [24, 26, $28,29]$. However, none of these assays utilized the SYBR 


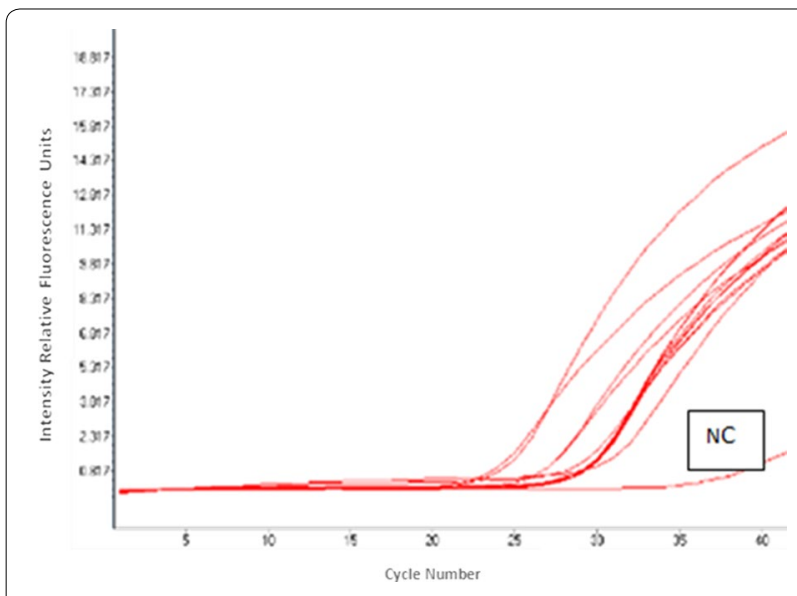

Fig. 8 Virus detection in tracheal swabs with SYBR green I real-time RT-PCR. Tracheal swabs (34) were taken from broiler chickens showing clinical signs of infectious bronchitis. A subset of the results from 34 tracheal swabs using SYBR green I real-time RT-PCR are shown. $N C$ negative control, RT-PCR reverse-transcriptase polymerase chain reaction
Table 2 Intra- and inter-assay reproducibility of SYBR green-I-based real-time RT-PCR

\begin{tabular}{llll}
\hline $\begin{array}{l}\text { Copy } \\
\text { number }\end{array}$ & $\begin{array}{l}\text { Mean } \\
\text { crossing point }\end{array}$ & $\begin{array}{l}\text { Intra-assay } \\
\text { CV (\%) }\end{array}$ & $\begin{array}{l}\text { Inter-assay } \\
\text { CV (\%) }\end{array}$ \\
\hline $10^{1}$ & 32.90 & 1.5 & 1.6 \\
$10^{2}$ & 28.25 & 1.2 & 1.8 \\
$10^{3}$ & 25.17 & 0.9 & 1.4 \\
$10^{4}$ & 21.84 & 0.7 & 1.2 \\
$10^{5}$ & 18.26 & 0.6 & 0.7 \\
$10^{6}$ & 16.63 & 0.6 & 0.6 \\
\hline
\end{tabular}

$C V$ coefficient of variation

green I chemistry for specific detection and quantification of IBV targeting the $\mathrm{N}$ gene. The main advantages of SYBR green I assays over other real-time PCR detection formats are: (1) SYBR green I is a low-cost fluorochrome; (2) SYBR green I assays are simpler to use, especially in regard to primer design and optimization procedures [25]; and (3) artifacts commonly observed in specific probes, particularly at amplification cycles beyond the 30th round, are minimal and can be ruled out by melting curve analysis. The assay described here is therefore ideal for establishing IB diagnostic capabilities in developing countries such as Morocco.

\section{Conclusions}

In conclusion, we report for the first time a one-step SYBR green I real-time RT-PCR protocol for IBV N gene detection. The assay is a sensitive, simple, efficient, and

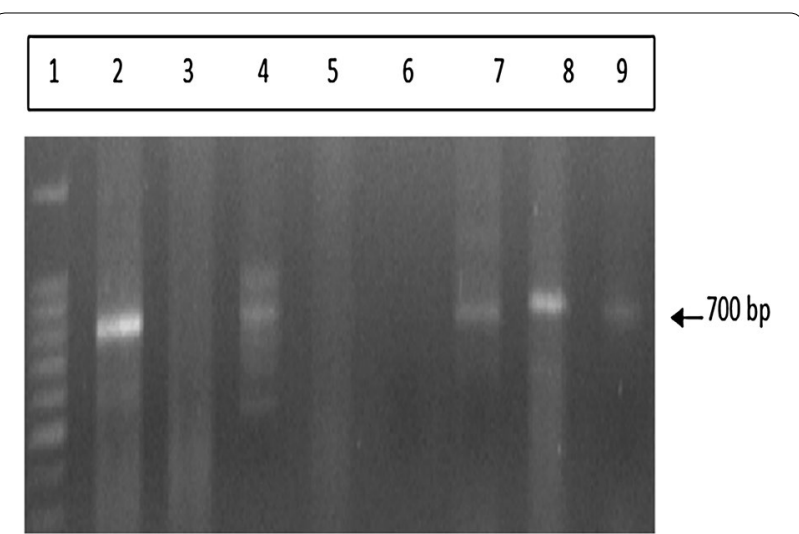

Fig. 9 Agarose gel electrophoresis of one-step RT-PCR amplified products of the IBV 51 gene. Commercial IBV vaccine (IBV H120, MA5, and 4/91) and field strains ("Moroccan 30" and "Moroccan 38") were separated by electrophoresis on a $1.5 \%$ agarose gel stained with ethidium bromide. Lane 1100 bp DNA ladder; lane 2 Moroccan 30 strain; lane 3 negative control; lane 4 Moroccan 38 strain; lanes 5, 6 negative controls; lane $7 \mathrm{Ma} 5$ commercial vaccine; lane $8 \mathrm{H} 120$ commercial vaccine; lane $94 / 91$ commercial vaccine. Product size, 700 bp. Bp base pairs, IBV infectious bronchitis virus, RT-PCR reverse transcriptasepolymerase chain reaction

cost-effective method that can be applied easily for laboratory diagnosis of IBV infections.

\section{Methods \\ Viruses}

IBV was propagated in 9-11-day-old embryonated specific pathogen-free chicken eggs as described previously [30]. The allantoic fluid was harvested $48 \mathrm{~h}$ post-inoculation and stored at $-80{ }^{\circ} \mathrm{C}$ until RNA extraction. The different viruses used in this study are listed in Table 3.

\section{Clinical standard samples}

To validate the reliability of SYBR green-I-based realtime RT-PCR, the quantified IBV Beaudette strain was used as the standard control, and allantoic fluid with different titers of the virus were obtained.

\section{Tracheal swabs from IBV-infected chickens}

Tracheal samples were obtained from the Avian Unit, Agronomy and Veterinary Institute Hassan II, Rabat, Morocco. These samples were identified during routine diagnostic efforts and stemmed from 34 commercial broiler chickens with clinical signs indicative of IB, including coughing, sneezing, rales, and nasal discharge. All samples had been confirmed to be IBV-positive by virus isolation, but serotypes were not determined. For this study, all samples were tested by SYBR green-I-based real-time RT-PCR and conventional RT-PCR. The swabs were suspended in $300 \mu$ of phosphate-buffered saline, 
Table 3 Viruses used in the study

\begin{tabular}{|c|c|c|}
\hline Virus & Strain & $\begin{array}{l}\text { Source } \\
\text { Type of vaccine }\end{array}$ \\
\hline \multirow[t]{4}{*}{$\begin{array}{l}\text { Infectious bronchitis } \\
\text { virus (IBV) }\end{array}$} & $\mathrm{H} 120$ & $\begin{array}{l}\text { Biopharma } \\
\text { Massachussetts serotype }\end{array}$ \\
\hline & Ma5 & $\begin{array}{l}\text { MSD Animal Health } \\
\text { Nobilis IB Ma5 vaccine }\end{array}$ \\
\hline & $4 / 91$ & $\begin{array}{l}\text { MSD Animal Health } \\
\text { Nobilis IB 4/91 vaccine }\end{array}$ \\
\hline & Beaudette & $\begin{array}{l}\text { Ploufragan-Plouzané } \\
\text { laboratory } \\
\text { Wild attenuated strain }\end{array}$ \\
\hline $\begin{array}{l}\text { Newcastle disease virus } \\
\text { (NDV) }\end{array}$ & Lasota & $\begin{array}{l}\text { Biopharma } \\
\text { HB1 type, LaSota strain }\end{array}$ \\
\hline $\begin{array}{l}\text { Infectious bursal } \\
\text { disease virus (IBDV) }\end{array}$ & Moroccan field strain & $\begin{array}{l}\text { Biopharma } \\
\text { Vaccine strain }\end{array}$ \\
\hline $\begin{array}{l}\text { Avian influenza A virus } \\
\text { (FLUAV) }\end{array}$ & H5N1 subtype & $\begin{array}{l}\text { Biopharma } \\
\text { Inactivated vaccine } \\
\text { strain }\end{array}$ \\
\hline
\end{tabular}

clarified by centrifugation at $1500 \times g$ at $4{ }^{\circ} \mathrm{C}$ for $15 \mathrm{~min}$, and incubated at room temperature for $1 \mathrm{~h}$. The viruscontaining supernatants obtained from the tracheal swabs were used for direct extraction of viral RNA.

\section{RNA extraction}

IBV RNA and negative control RNA (NDV [183.6 ng/ $\mu \mathrm{l}]$, IBDV $[67.5 \mathrm{ng} / \mu \mathrm{l}]$, FLUAV $[92.1 \mathrm{ng} / \mu \mathrm{l}])$ were extracted from $140 \mu \mathrm{l}$ of supernatant from allantoic fluid using the QIAamp Viral RNA or RNeasy Mini Kits (Qiagen, Valencia, CA, USA) according to the manufacturer's instructions. Each RNA fraction was eluted in $50 \mu \mathrm{l}$ of RNase-free water.

\section{SYBR green-I-based real time RT PCR}

SYBR green I-based real time RT-PCR was performed using a primer pair consisting of (a) downstream primer, AIBV-fr, targeting $\mathrm{N}$ gene nucleotide positions 811-832 (5'-ATGCTCAACCTTGTCCCTAGCA-3'); and (b) upstream primer, $\mathrm{AIBV}$-as, targeting $\mathrm{N}$ gene nucleotide positions 921-941 (5'-TCAA-ACTGCGGATCA-TC ACGT-3', TIB Molbiol, Berlin, DE) as previously described by Meir et al. [9]. To minimize primer-dimer formation, primer set concentration and thermocycling conditions were both optimized (data not shown).

PCRs were performed on a Light Cycler (Roche Diagnostics Ltd. Rotkreuz, $\mathrm{CH}$ ). Each reaction was carried out using $5 \mu \mathrm{l}$ of purified RNA and $20 \mu \mathrm{l}$ of a reaction mixture, containing $0.5 \mu \mathrm{l}$ of RT (50 U) (Applied Biosystems, Grand Island, NY, USA), $0.5 \mu$ l of RNase inhibitor (20 U), $0.5 \mu \mathrm{l}$ of $\mathrm{MgCl}_{2}(50 \mathrm{mM}), 2 \mu \mathrm{l}$ of FastStart DNA Master Mix SYBR green I (containing Taq DNA polymerase, SYBR green I, deoxynucleotide triphosphate mix [Life Technologies, Grand Island, NY, USA]), and $0.5 \mu \mathrm{l}$ of the two primers (final concentration of each primer is $10 \mu \mathrm{M}$ ) and enough nuclease-free water (Promega, Madison, WI, USA) for a final volume of $20 \mu \mathrm{L}$ for each reaction. The thermal profile consisted of $10 \mathrm{~min}$ of reverse transcription at $50{ }^{\circ} \mathrm{C}$, 10 min of hot-start enzyme activation at $95^{\circ} \mathrm{C}$, followed by 45 cycles of PCR at $95^{\circ} \mathrm{C}$ for $10 \mathrm{~s}$ (denaturation), $58^{\circ} \mathrm{C}$ for $20 \mathrm{~s}$ (annealing), and $72{ }^{\circ} \mathrm{C}$ for $30 \mathrm{~s}$ (elongation). To avoid cross contamination and sample carryover, pre- and postPCR sample processing were performed in separate rooms. Plugged pipette tips were used to transfer all fluids to eliminate aerosols. Amplified cDNA products were detected by melting curve analysis that consisted of $95{ }^{\circ} \mathrm{C}$ for $5 \mathrm{~s}$ and $65{ }^{\circ} \mathrm{C}$ for $60 \mathrm{~s}$, and heated to $97{ }^{\circ} \mathrm{C}$ to measure continuous changes in fluorescence of SYBR green I. Following amplification, a melting curve analysis was performed with the Light Cycler instrument's software (software release 1.5.0, version 1.5.0.39) according to the instructions of the manufacturer. Negative template control (diethyl pyrocarbonate-treated water) and positive template controls (i.e., NDV, IBDV, FLUAV) were included with each PCR run. Each strain used was tested in triplicate.

\section{Reproducibility of SYBR green-I-based real-time RT-PCR}

To evaluate reproducibility of the assay, quantification analysis of IBV cDNA was developed using the 34 clinical standard samples from Moroccan broiler chickens. cDNA of the genomic RNA of IBV Beaudette strain was used as the source of DNA templates. After quantification, IBV Beaudette strain cDNA was serially diluted $\left(10^{6}-10\right.$ copies $\left./ \mu \mathrm{l}\right)$ and used as a standard control. Three separate dilution series were assayed in a single run to evaluate intra-assay variations, whereas inter-assay variations were measured by testing each dilution in three separate consecutive runs. The standard deviation (SD) was calculated using Light Cycler Software 480 version 1.5 (Roche Diagnostics Ltd. Rotkreuz, CH). The coefficient of variation $(\mathrm{CV})$ was determined following the formula $\mathrm{CV}=(\mathrm{SD}[\mathrm{Ct}$-value]/overall mean [Ct-value] $) \times 100$.

\section{Sensitivity of SYBR green-I-based real-time RT-PCR}

The sensitivity of the SYBR green-I-based real-time RTPCR assay was tested by the limiting dilution assay [31]. Genomic RNA from attenuated Massachusetts serotype H120 vaccine was then diluted to $\approx 100(151.6 \mathrm{ng} / \mu \mathrm{l}), 20$ (35.6 ng/ $\mu \mathrm{l}), 5(12.9 \mathrm{ng} / \mu \mathrm{l})$, and $1.25(0.7 \mathrm{ng} / \mu \mathrm{l}) \mathrm{copies} / \mu \mathrm{l}$ as previously described [32]. The tubes at each concentration were assayed using the forward and reverse primers. Samples with $\mathrm{Ct}$ values of less than 32 were considered positive.

\section{Conventional reverse transcriptase polymerase chain reaction}

Conventional RT-PCR was performed in a thermal cycler (Techne, Staffordshire, UK), according to the instructions 
provided by the manufacturer. The RT-PCR was performed in one step, in a final volume of $20 \mu$ l. Briefly, the final volume consisted of $2.5 \mu \mathrm{l}$ of buffer, $2.5 \mu \mathrm{l}$ of $\mathrm{MgCl}_{2}$ (25 mM), $2.5 \mu \mathrm{l}$ of deoxyribonucleotide triphosphates $(10 \mathrm{mM}), 9.7 \mu \mathrm{l}$ of water, $0.5 \mu \mathrm{l}$ of RNase inhibitor $(20 \mathrm{U})$, $0.3 \mu \mathrm{l}$ of reverse transcriptase ( $50 \mathrm{U}$ ), $0.5 \mu \mathrm{l}$ of Taq polymerase (Gold) $(5 \mathrm{U})$, and $0.75 \mu \mathrm{l}$ of each of the primers (forward and reverse) $(10 \mu \mathrm{M})$.

One step, reverse transcription was performed at $48{ }^{\circ} \mathrm{C}$ for $30 \mathrm{~min}$ and $95^{\circ} \mathrm{C}$ for $5 \mathrm{~min}$. cDNA was amplified through a 35 -cycle PCR consisting of denaturation at $94{ }^{\circ} \mathrm{C}$ for $30 \mathrm{~s}$, annealing at $52{ }^{\circ} \mathrm{C}$ for $30 \mathrm{~s}$, and extension at $72{ }^{\circ} \mathrm{C}$ for $30 \mathrm{~s}$, with one final extension cycle at $72{ }^{\circ} \mathrm{C}$ for $10 \mathrm{~min}$. The amplified PCR products of the $\mathrm{N}$ gene were evaluated by $1.5 \%$ agarose gel electrophoresis in Tris-borate-EDTA buffer stained with ethidium bromide (Promega).

\section{Comparison of sensitivity and specificity of SYBR green I real-time RT-PCR with conventional RT-PCR assay}

The analytical sensitivity and specificity of the SYBR green I real-time RT-PCR assay were determined by testing sequential tenfold dilutions of the in vitro-transcribed RNA, which were obtained as previously described, in nuclease-free water (Promega).

\section{One-step RT-PCR amplification of the IBV S1 gene}

PCR amplification of the IBV $S$ gene was carried out using commercial vaccines (H120, Ma5 and 4/91) and field strains, "Moroccan 30" and "Moroccan 38" from chickens with respiratory signs. Each $25 \mu \mathrm{l}$ of PCR reaction mixture consisted of $2.5 \mu \mathrm{l}$ of buffer (10X), $2.5 \mu \mathrm{l}$ of $\mathrm{MgCl}_{2}(25 \mathrm{mM}), 2.5 \mu \mathrm{l}$ of deoxynucleotide triphosphates $(10 \mathrm{mM}), 0.75 \mu \mathrm{l}$ of each primer $(10 \mu \mathrm{M})(\mathrm{CK} 2$ and S15mod) [19], and $9.7 \mu \mathrm{l}$ of sterilized water. At the end, $0.5 \mu \mathrm{l}$ of RNAase inhibitor $(20 \mathrm{U} / \mu \mathrm{l}), 0.3 \mu \mathrm{l}$ of RT (50 $\mathrm{U} / \mu \mathrm{l}), 0.5 \mu \mathrm{l}$ of Taq gold polymerase (ThermoFisher Scientific) $(5 \mathrm{U} / \mu \mathrm{l})$, and $5 \mu \mathrm{l}$ of IBV RNA were added. This one-step RT-PCR reaction was carried out using Smart Thermal Cycler, (Smart Cycler Cepheid, Sunnyvale, CA, USA) following the protocol of $48^{\circ} \mathrm{C}$ for $30 \mathrm{~min}, 95^{\circ} \mathrm{C}$ for $5 \mathrm{~min}, 40$ cycles of $95^{\circ} \mathrm{C}$ for $30 \mathrm{~s}, 52^{\circ} \mathrm{C}$ for $30 \mathrm{~s}, 72^{\circ} \mathrm{C}$ for $30 \mathrm{~s}$, and a final extension cycle of $72^{\circ} \mathrm{C}$ for $10 \mathrm{~min}$.

\section{Nucleotide sequencing and sequence analysis}

Following amplification, $20 \mu \mathrm{l}$ of each S1 PCR reaction for "Moroccan 30" and "Moroccan 38" field strains and vaccine strains (H120, Ma5 and 4/91) were subjected to $1.5 \%$ agarose gel electrophoresis (under $70 \mathrm{~V}$ for $30 \mathrm{~min}$ ) and stained with ethidium bromide. The appropriate bands were excised and purified using the Gene Clean Kit (ExoSAP-IT, Affymetrix, Santa Clara, CA, USA) according to the manufacturer's recommendations. Nucleotide sequences were determined using the same primers (S15mod and CK2) [19] and the BigDye ${ }^{\circledR}$ Terminator v1.1 Cycle Sequencing Kit (Life Technologies, Grand Island, NY, USA). The second purification was performed by Big Dye $\mathrm{X}$ terminator Purification Kit.

\section{Statistical analysis}

The significant differences among the mean of the $\mathrm{Ct}$ values corresponding to each viral dilution were analyzed by one-way analysis of variance (ANOVA) using Statistical Package for the Social Sciences (SPSS) Version 13 software (IBM, Armonk, NY, USA). A receiver operating characteristic curve statistical test was used to compare the sensitivity and specificity of the SYBRgreen-I-based real-time RT-PCR over the conventional RT-PCR. A $p$ value of less than 0.05 is considered statistically significant.

\section{Abbreviations}

bp: base pairs; Ct: cycle threshold; ELISA: enzyme-linked immunosorbent assay; FLUAV: avian influenza virus; IB: infectious bronchitis; IBDV: infectious bursal disease virus; IBV: infectious bronchitis virus; M: membrane protein; N: nucleocapsid protein; NC: negative control; NDV: newcastle disease virus; RNA: ribonucleic acid; RT-PCR: reverse transcriptase-polymerase chain reaction; S: spike protein.

\section{Authors' contributions}

MME conceived the study, and SF, MEH, MME participated in the design of the study. SF, KK, and MEH analyzed and interpreted data. SF, MEH, GS, and MME drafted and SF, MEH, and JHK edited the manuscript. EB participated in the statistical analyses. SF and KK participated in the molecular analyses. OFF participated in virus sequencing. All authors read and approved the final manuscript.

\section{Author details}

${ }^{1}$ Unit of Avian Pathology, Agronomic and Veterinary Institute Hassan II, B.P. 6202, Rabat, Morocco. ${ }^{2}$ Laboratory of Virology, Microbiology and Quality/ Ecotoxicology \& Biodiversity, Faculty of Sciences and Techniques-University Hassan II Mohammedia, PO Box 146, Quartier Yasmina-Mohammedia, 20650 Casablanca, Morocco. ${ }^{3}$ Laboratory of Molecular Biology-Society of Biological Products and Veterinary Pharmaceuticals (Biopharma), B.P. 4569, Km 2, Route de Casa, Rabat, Morocco. ${ }^{4}$ Integrated Research Facility at Fort Detrick, National Institute of Allergy and Infectious Diseases, National Institutes of Health, B-8200 Research Plaza, Fort Detrick, Frederick, MD 21702, USA

${ }^{5}$ Laboratory of Epidemiology and Clinical Research. Faculty of Medicine, B.P. 1014, 4, Avenue Ibn Battouta, Rabat, Morocco.

\section{Acknowledgements}

We thank Laura Bollinger (Integrated Research Facility at Fort Detrick) for providing Technical Writing Services in critically editing this manuscript on behalf of Battelle Memorial Institute.

\section{Competing interests}

The authors declare that they have no competing interests.

\section{Sources of support}

The content of this publication does not necessarily reflect the views or policies of the US Department of Health and Human Services (DHHS) or of the institutions and companies affiliated with the authors. This work was funded in part through Battelle Memorial Institute's prime contract with the US National Institute of Allergy and Infectious Diseases (NIAID) under Contract No. HHSN272200700016l. A subcontractor to Battelle Memorial Institute who performed this work is JHK, an employee of Tunnell Government Services, Inc. The Agronomic and Veterinary Institute Hassan II, Rabat, Morocco, Ministry of 
Higher Education of Morocco, University Hassan II Mohammedia-Casablanca, Mohammedia, Morocco, and the Society of Biological Products and Veterinary Pharmaceuticals (Biopharma), Rabat, Morocco, sponsored the molecular analyses and sequencing of the different samples.

Received: 1 February 2015 Accepted: 11 April 2016

Published online: 22 April 2016

\section{References}

1. Cavanagh D. Coronavirus avian infectious bronchitis virus. Vet Res. 2007;38(2):281-97.

2. Keeler CL Jr, Reed KL, Nix WA, Gelb J Jr. Serotype identification of avian infectious bronchitis virus by RT-PCR of the peplomer (S-1) gene. Avian Dis. 1998;42(2):275-84.

3. Callison SA, Riblet SM, Oldoni I, Sun S, Zavala G, Williams S, Resurreccion RS, Spackman E, Garcia M. Development and validation of a real-time Taqman PCR assay for the detection and quantitation of infectious laryngotracheitis virus in poultry. J Virol Methods. 2007;139(1):31-8.

4. Alarabi MAH: A field study of kidney disease among the broiler flocks in Morocco and its relationship to infectious bronchitis virus. Ph.D thesis. Agronomic and Veterinary Institute Hassan II, Rabat; 2004.

5. El Bouqdaoui M, Mhand RA, Bouayoune H, Ennaji MM. Genetic grouping of nephropathogenic avian infectious bronchitis virus isolated in Morocco. Int J Poult Sci. 2005:4:721-7.

6. El-Houadfi M, Jones RC, Cook JK, Ambali AG. The isolation and characterisation of six avian infectious bronchitis viruses isolated in Morocco. Avian Pathol. 1986;15(1):93-105.

7. King AMQ, Adams MJ, Carstens EB, Lefkowitz EJ, eds. Virus taxonomy: classification and nomenclature of viruses: Ninth Report of the International Committee on Taxonomy of Viruses. San Diego: Elsevier Academic Press; 2012. http://www.ictvonline.org/index.asp?bhcp=1. Accessed 19 Sept 2014.

8. Lai MM, Cavanagh D. The molecular biology of coronaviruses. Adv Virus Res. 1997;48:1-100.

9. Meir R, Maharat O, Farnushi Y, Simanov L. Development of a real-time TaqMan RT-PCR assay for the detection of infectious bronchitis virus in chickens, and comparison of RT-PCR and virus isolation. J Virol Methods. 2010;163(2):190-4.

10. Kwon HM, Jackwood MW, Gelb J Jr. Differentiation of infectious bronchitis virus serotypes using polymerase chain reaction and restriction fragment length polymorphism analysis. Avian Dis. 1993;37(1):194-202.

11. Karaca K, Naqi S. A monoclonal antibody blocking ELISA to detect serotype-specific infectious bronchitis virus antibodies. Vet Microbiol. 1993;34(3):249-57.

12. Karaca K, Naqi S, Gelb J Jr. Production and characterization of monoclonal antibodies to three infectious bronchitis virus serotypes. Avian Dis. 1992;36(4):903-15.

13. Naqi SA, Karaca K, Bauman B. A monoclonal antibody-based antigen capture enzyme-linked immunosorbent assay for identification of infectious bronchitis virus serotypes. Avian Pathol. 1993;22(3):555-64.

14. Jackwood MW, Yousef NM, Hilt DA. Further development and use of a molecular serotype identification test for infectious bronchitis virus. Avian Dis. 1997;41(1):105-10.

15. Kingham BF, Keeler CL Jr, Nix WA, Ladman BS, Gelb J Jr. Identification of avian infectious bronchitis virus by direct automated cycle sequencing of the S-1 gene. Avian Dis. 2000;44(2):325-35.

16. Cavanagh D, Davis P, Cook J, Li D. Molecular basis of the variation exhibited by avian infectious bronchitis coronavirus (IBV). Adv Exp Med Biol. 1990;276:369-72.
17. Callison SA, Hilt DA, Boynton TO, Sample BF, Robison R, Swayne DE, Jackwood MW. Development and evaluation of a real-time Taqman RT-PCR assay for the detection of infectious bronchitis virus from infected chickens. J Virol Methods. 2006;138(1-2):60-5.

18. Hairul Aini H, Omar AR, Hair-Bejo M, Aini I. Comparison of Sybr Green I, ELISA and conventional agarose gel-based PCR in the detection of infectious bursal disease virus. Microbiol Res. 2008;163(5):556-63.

19. Eterradossi N, Britton P: Avian infectious bronchitis. In: Biological Standards Commission, editor. Manual of diagnostic tests and vaccines for terrestrial animals. edn. World Organisation for Animal Health; 2013. http:// www.oie.int/fileadmin/Home/eng/Health_standards/tahm/2.03.02_AlB. pdf. Accessed 2 May 2014.

20. De Wit JJ. Detection of infectious bronchitis virus. Avian Pathol. 2000;29(2):71-93.

21. Mackay IM. Real-time PCR in the microbiology laboratory. Clin Microbiol Infect. 2004;10(3):190-212.

22. Cavanagh D, Mawditt K, Britton P, Naylor C. Longitudinal field studies of infectious bronchitis virus and avian pneumovirus in broilers using typespecific polymerase chain reactions. Avian Pathol. 1999;28(6):593-605.

23. Handberg $K$, Nielsen $O$, Pedersen $M$, Jorgensen P. Detection and strain differentiation of infectious bronchitis virus in tracheal tissues from experimentally infected chickens by reverse transcription-polymerase chain reaction. Comparison with an immunohistochemical technique. Avian Pathol. 1999;28(4):327-35.

24. Acevedo AM, Perera CL, Vega A, Rios L, Coronado L, Relova D, Frias MT, Ganges L, Nunez Jl, Perez LJ. A duplex SYBR Green I-based real-time RT-PCR assay for the simultaneous detection and differentiation of Massachusetts and non-Massachusetts serotypes of infectious bronchitis virus. Mol Cell Probes. 2013;27(5-6):184-92.

25. Aldea C, Alvarez CP, Folgueira L, Delgado R, Otero JR. Rapid detection of herpes simplex virus DNA in genital ulcers by real-time PCR using SYBR green I dye as the detection signal. J Clin Microbiol. 2002;40(3):1060-2.

26. Cavanagh D, Gelb J: Infectious bronchitis. In: Saif Y, editor. Diseases of poultry, 12 edn. Ames: Blackwell Publishing Professional; 2008. p. 117-30. https://www.himakahaunhas.files.wordpress.com/2013/2003/disease-ofpoultry.pdf.

27. Spencer KA, Hiscox JA. Expression and structural analysis of infectious bronchitis virus nucleoprotein. Adv Exp Med Biol. 2006;581:133-8.

28. Escutenaire S, Mohamed N, Isaksson M, Thoren P, Klingeborn B, Belak S, Berg M, Blomberg J. SYBR Green real-time reverse transcription-polymerase chain reaction assay for the generic detection of coronaviruses. Arch Virol. 2007;152(1):41-58

29. Fan WQ, Wang HN, Zhang Y, Guan ZB, Wang T, Xu CW, Zhang AY, Yang $X$. Comparative dynamic distribution of avian infectious bronchitis virus M41, H120, and SAIBK strains by quantitative real-time RT-PCR in SPF chickens. Biosci Biotechnol Biochem. 2012;76(12):2255-60.

30. Villarreal LY, Brandao PE, Chacon JL, Saidenberg AB, Assayag MS, Jones RC, Ferreira AJ. Molecular characterization of infectious bronchitis virus strains isolated from the enteric contents of Brazilian laying hens and broilers. Avian Dis. 2007;51(4):974-8.

31. Taswell C. Limiting dilution assays for the determination of immunocompetent cell frequencies. I. Data analysis. J Immunol. 1981;126(4):1614-9.

32. Chandriani S, Ganem D. Array-based transcript profiling and limitingdilution reverse transcription-PCR analysis identify additional latent genes in Kaposi's sarcoma-associated herpesvirus. J Virol. 2010;84(11):5565-73. 